Уршуля Кемпінська

Куявська вища школа у Влоцлавку, м. Влоцлавек, Польща ORCID ID 0000-0003-1922-8219

Олена Біда Закарпатський угорський інституту ім. Ференца Ракоці II ORCID ID 0000-0002-0448-0852

Тетяна Кучай Закарпатський угорський інститут ім. Ференца Ракоці II, М. Берегово ORCID ID 0000-0003-3518-2767

Олександр Кучай Національний університет біоресурсів і природокористування України ORCID ID 0000-0002-9468-0486

Наталія Рокосовик Відкритий міжнародний університет розвитку людини «Україна» ORCID ID 0000-0002-5588-8655

DOI 10.24139/2312-5993/2020.10/025-031

\title{
ПРОБЛЕМИ ЕСТЕТИЧНОГО ВИХОВАННЯ МОЛОДІ В СУЧАСНИХ УМОВАХ РОЗВИТКУ СУСПІЛЬСТВА
}

у статті розкрито проблеми естетичного виховання молоді в сучасних умовах розвитку суспільства. Естетичне виховання повинно сприяти формуванню творчо активної особистості. Виокремлено найголовніші завдання естетичного виховання. Естетичне виховання зорієнтоване на формування естетичної свідомості та естетичної поведінки особистості. Формування справжніх естетикодуховних цінностей студентської молоді неможливе без глибокого усвідомлення ними національних основ культури. Одним із найсильніших факторів стихійного естетичного впливу в системі естетичного виховання є природа. Ефрективність естетичного виховання студентів значною мірою залежить від умілого використання педагогами різноманітних способів і засобів. Естетичне виховання студентської молоді передбачає якісну зміну рівня їх естетичної культури.

Ключові слова: естетичне виховання, молодь, культура, освіта, духовні цінності.

Постановка проблеми. Українська педагогічна наука й освітньовиховна практика, увібравши найновіші досягнення сучасної педагогічної теорії, прагне забезпечити підготовку молодого покоління українців до життя в нових суспільних умовах, сформувати в них готовність, прагнення активно впливати на утвердження нових суспільних ідеалів і духовних цінностей, формування художньо-естетичної культури.

Питання естетичного виховання особистості набувають особливого значення в сучасних умовах розвитку суспільства, коли загострюються суспільні суперечності, втрачаються загальнолюдські цінності, життєві ідеали, мають місце рецидиви аморальної поведінки молоді. Естетичне 
виховання повинно сприяти формуванню творчо активної особистості, здатної повноцінно сприймати прекрасне, гармонійне, досконале в житті, природі, мистецтві, жити та творити за законами краси.

Підготовка підростаючого покоління до життя в сучасному суспільстві можлива за умови реформування вітчизняної школи. її важливим завданням $€$ створення інноваційної педагогічної інфраструктури, що охоплюватиме естетику предметного середовища, в якому школярі зможуть реалізувати свої художньо-творчі здібності (мистецькі світлиці, художні майстерні, сучасний дизайн шкільних інтер'єрів), і естетику соціально-педагогічного середовища (естетика шкільного спілкування й життєтворчості, краса міжособистісних відносин, панування педагогічного оптимізму й віри, що кожна дитина - в душі митець) (Мочан, 2011).

Аналіз актуальних досліджень. Проблемі естетичного виховання присвячені праці Л.Глазунова, Д. Кабалевського, А. Макаренка, Л. Михайлової, Т. Мочан, Б. Неменського, О. Степанова, В. Сухомлинського, К. Ушинського та інших.

Мета статті: розкрити проблеми естетичного виховання молоді в сучасних умовах розвитку суспільства.

Методи дослідження. Для досягнення поставленої мети використано такі методи дослідження: теоретичні (аналіз філософської, педагогічної, психологічної літератури), що дає змогу обґрунтувати вихідні положення дослідження; інтерпретаційно-аналітичний метод, на основі якого вивчаються джерела із застосуванням синтезу, аналізу, систематизації та узагальнення.

Виклад основного матеріалу. Естетичне виховання покликане ознайомити людину із загальними закономірностями художнього освоєння дійсності, сутністю й формами відображення дійсності й перетворення життя за законами краси, роллю мистецтва в розвитку суспільства.

Серед найголовніших завдань естетичного виховання виокремлюють:

- формування естетичних понять, поглядів, переконань, здатностей розуміти прекрасне, правильно естетично оцінювати факти, явища, процеси;

- виховання естетичних почуттів, уміння отримувати насолоду від сприймання прекрасного в навколишній дійсності та мистецтві;

- формування потреби та здатності створювати прекрасне в житті й мистецтві на основі розвитку власних творчих здібностей, опанування знань і практичних умінь у певному виді мистецтва. 
В естетичному вихованні молоді використовують різні джерела прекрасного: образотворче мистецтво, музику, літературу, театр, кіно, архітектуру тощо. Так, під час сприйняття картини або скульптури дитина не лише пізнає світ, але й фантазує, формує, «домальовує» подумки зображене, бачить на картині події, образи, характери. Чільне місце посідає також музика, яка, відображаючи дійсність за допомогою мелодій, інтонацій, тембру, впливає на емоційно-почуттєву сферу людини, їі поведінку. Важливим джерелом є й художня література.

Головним виразником естетики в літературі $\epsilon$ слово. На думку К. Ушинського, слово як засіб вираження в літературному творі набуває подвійної художньої сили. Словесний образ має ще й понятійну основу та сприймається насамперед розумом. Тому література - важливий засіб розвитку інтелекту учнів. Цінність театру, кіно, телебачення, естради, цирку як засобів естетичного виховання в тому, що вони поєднують у собі елементи багатьох видів мистецтва: літератури, музики, образотворчого мистецтва, танцю. Повинна стати предметом обговорення з естетичних позицій і діяльність школярів: гідні вчинки учнів, їх успіхи в навчанні, праці, спортивній, громадській, художній діяльності.

Учитель має показати дитині красу природи в розмаїтті та гармонії барв, звуків, форм, закономірній зміні явищ. Предметом захоплення повинні стати також героїчні вчинки людей, краса їх взаємин, духовне багатство, моральна чистота й фізична досконалість. Важливим засобом естетичного виховання може слугувати дизайн шкільних приміщень, оформлення класу.

Особливим фактором естетичного виховання $\epsilon$ природа. Як зауважував В. Сухомлинський, розглядаючи квітку чи окрему пелюстку, крильце метелика чи пушинку тополі, дитина не повинна забувати глобальну істину: природа - це єдине ціле, якому притаманна гармонія взаємозв'язків і залежностей, яке є джерелом і сутністю життя.

Естетичне виховання зорієнтоване на формування естетичної свідомості та естетичної поведінки особистості (Степанов, 2006).

В основу естетичного виховання молоді покладено ядро художньої культури - мистецтво як унікальна форма суспільної свідомості, що сприяє духовному розвитку й удосконаленню внутрішнього світу людини. Про значення мистецтва в естетичному розвитку особистості відомо ще з часів Античної Греції - філософські й літературні доробки, культурологічні та історичні пам'ятки вказують на його провідну роль у вихованні гармонійно розвиненої людини (Михайлова, 2009). 
Естетичне виховання студентської молоді передбачає якісну зміну рівня їх естетичної культури, яким може бути охоплена як окрема особистість, соціальна група, так і суспільство в цілому. Це безперервний процес протягом усього життя людини, завдяки якому розв'язуються протиріччя між рівнем естетичної культури людства й певною культурою окремої особистості в кожному окремому періоді життя (Глазунова, 2014).

Естетичне ставлення до життя визначає такі особистісні тенденції: бачення, розуміння, освоєння, створення краси й гармонії у праці, пізнанні, ставленні до природи, людей, самого себе; потреба в як найповнішому розкритті естетичного змісту життя, розвиток естетичних почуттів; естетичних дій як необхідний елемент будь-якої діяльності, загальна естетизація життя як вияв високої духовної культури, художня творчість у різних формах тощо.

Залучення учнівської молоді до колективних форм творчої діяльності, в яких особливе місці має належати організаційно оформленим творчим колективам чи групам учнів, створених на добровільних засадах, і які мають спільні інтереси та потреби в проведенні свого дозвілля, сприяє їх естетичному вихованню. Кожен вид мистецтва доповнює та збагачує естетичне виховання учнівської молоді, підсилює їхні естетичне сприйняття, формує ті грані особистості, які найбільше підвладні його впливові.

Мистецтво впливає і на розвиток морально-естетичних та інтелектуальних почуттів творчої особистості. Завдяки плідному спілкуванню з мистецтвом, молоді люди набувають досвіду, вчаться оцінювати різні життєві ситуації, відповідально ставитися до себе й результатів своєї праці, що облагороджує важливі напрями їхньої життєдіяльності, сприяє вихованню духовної культури, творчого мислення.

Для сьогодення вкрай важливим є твердження, що засобами різних видів мистецтва можна спонукати учнівську молодь до активного й осмисленого сприймання музики, малярства, скульптури, архітектури, фільмів, вистав; сприяти інтелектуальному, емоційному, динамічному сприйняттю творів мистецтва, вводячи учня у світ загальнолюдських цінностей за допомогою художніх образів; активізувати такі психологічні процеси, як пам'ять, уява, фантазія, формуючи тим самим творчу особистість, здатну висловлювати через слово свої почуття й розуміння мистецьких творів; сприяти кращому засвоєнню програмового матеріалу шляхом участі різних органів чуття (зорових, слухових); забезпечити єдність навчання й виховання шляхом розвитку інтелекту, розширення світогляду й формування естетичних уподобань, моральних принципів, критичного ставлення до низькопробних творів; акцентуючи увагу на найкращих 
мистецьких творах, давати учням певний обсяг знань, необхідний для аналізу, формувати вміння й навички роботи 3 ними, водночас удосконалюючи їхні знання (Мочан, 2011).

Формування справжніх естетико-духовних цінностей студентської молоді неможливе без глибокого усвідомлення ними національних основ культури, зокрема народної пісні, творчості українських композиторівкласиків. Надзвичайно важливим є цілісний підхід до засвоєння ними національної культури: вивчення історії, оволодіння естетичним багатством мови, увага до краси рідного краю. Одним з найсильніших факторів стихійного естетичного впливу в системі естетичного виховання $є$ природа. Цей вплив посилюється за умови, що він організований і керований педагогом.

Естетичне виховання студентів здійснюється і шляхом міжособистісного впливу між студентами, студентами й викладачами в освітньому процесі та в позанавчальний час. Естетичне спілкування, яке включає елементарні естетичні навички поведінки, естетику взаємовідносин людей у праці, побуті, відпочинку, за умілої організації має потужну виховну силу. Формування естетичних відносин у закладі освіти відбувається за участі викладачів і кураторів.

Ефективність естетичного виховання студентів значною мірою залежить від умілого використання педагогами різноманітних способів і засобів: створення естетичних ситуацій, які передбачають оцінювання (ознайомлення з творами мистецтва та їх обговорення); використання естетичного потенціалу всіх навчальних дисциплін; упровадження естетичних елементів у структуру знань та ін.

Формування естетичної культури залежить від багатьох факторів. Серед них технократизм (надання переваги технічним дисциплінам), який протиставляє матеріальну культуру духовній. Це призводить до викривлення самої духовної культури, виникнення її неповноцінних форм. Тому в тих закладах освіти, де спостерігається це явище, необхідно вносити в освітній процес гуманістичний сенс, гуманітаризувати свідомість студентів (Естетичне виховання студентів, 2020).

Висновки та перспективи подальших наукових розвідок. Узагальнюючи вище сказане, можна засвідчувати, що питання виховання естетичної культури молоді є надзвичайно актуальним і необхідним. Лише естетично та морально багата генерація зможе розбудувати сильну державу та змінити стандарти поведінки в сучасному суспільстві. Вважаємо за необхідність уведення в освітній процес закладів загальної освіти новітніх ефективних методик, які сприяли б вихованню естетичної культури молоді та їі розвитку в цілому. 


\section{ЛITEPATУРА}

Мочан, Т. (2011). Естетичне виховання учнівської молоді у процесі творчої діяльності. Науковий вісник Ужгородського національного університету. Серія: Педагогіка. Сочіальна робота, 20, 85-88. (M ochan, T. (2011). Aesthetic education of student youth in the process of creative activity. Scientific Bulletin of Uzhhorod National University. Series: Pedagogy. Social work, 20, 85-88).

Степанов, О. (2006). Основи психології $i$ педагогіки. Режим доступу: https://subject.com.ua/psychology/psyho pedagog/118.html (Stepanov, 0. (2006). Fundamentals of psychology and pedagogy. Retrieved from: https://subject.com.ua/psychology/psyho pedagog/118.html).

Михайлова, Л. М. (2009). Естетичне виховання молоді: компетентісний підхід. Вісник НтуУ «КПІ». Філософрія. Психологія. Педагогіка, 1 (25), 158-162. (Mikhailova, L. M. (2009). Aesthetic education of youth: a competent approach. Bulletin of NTUU "KPI". Philosophy. Psychology. Pedagogy, 1 (25), 158-162).

Глазунова, Л. О. (2014). Естетичне виховання студентської молоді. Інноваційні підходи до виховання студентської молоді у вищих навчальних закладах: матеріали Міжнар. наук.-практ. конференції (м. Житомир, 22-23 травня 2014 р.). Житомир: Вид-во ЖДУ ім. І. Франка, сc. 203-209. (Glazunova, L. О. (2014). Aesthetic education of student youth. Innovative approaches to the education of student youth in higher education: materials International. scientific-practical Conference (Zhytomyr, M ay 2223, 2014). Zhytomyr: ZhSU Publishing House. I. Franko, pp. 203-209.).

Естетичне виховання студентів (2020). Режим доступу:

https://pidru4niki.com/70184/pedagogika/estetichne vihovannya studentiv

(Aesthetic education of students (2020). URL:

https://pidru4niki.com/70184/pedagogika/estetichne_vihovannya_studentiv).

\section{PEЗЮME}

Кемпинска Уршуля, Бида Елена, Кучай Татьяна, Кучай Александр, Рокосовик Наталья. Проблемы эстетического воспитания молодежи в современных условиях развития общества.

В статье раскрыты проблемы эстетического воспитания молодежи в современных условиях развития общества. Эстетическое воспитание должно способствовать формированию творчески активной личности. Выделены главные задачи эстетического воспитания. Эстетическое воспитание ориентировано на формирование эстетического сознания и эстетической поведения личности. Формирования настоящих эстетико-духовных ценностей студенческой молодежи невозможно без глубокого осознания ими национальных основ культуры. Одним из самых сильных факторов стихийного эстетического воздействия в системе естетического воспитания является природа. Эффрективность эстетического воспитания студентов в значительной степени зависит от умелого использования педагогами различных способов и средств. Эстетическое воспитание студенческой молодежи предусматривает качественное изменение уровня их эстетической культуры.

Ключевые слова: эстетическое воспитание, молодеж, культура, образование, духовные ценности.

\section{SUMMARY}

Kempinska Urszula, Bida Olena, Kuchai Tetiana, Kuchai Olexander, Rokosovyk Natalia. Problems of aesthetic education of youth in modern conditions of society.

The article reveals the problems of aesthetic education of youth in modern conditions of society. Aesthetic education should contribute to the formation of a creatively active 
personality. The most important tasks of aesthetic education are singled out. Aesthetic education is focused on the formation of aesthetic consciousness and aesthetic behavior of the individual. The formation of true aesthetic and spiritual values of student youth is impossible without a deep awareness of the national foundations of culture. One of the strongest factors of spontaneous aesthetic influence in the system of aesthetic education is nature. The effectiveness of aesthetic education of students largely depends on the skillful use by teachers of various ways and means. Aesthetic education of student youth involves a qualitative change in the level of their aesthetic culture.

Formation of true aesthetic and spiritual values of student youth is impossible without a deep awareness of the national foundations of culture, including folk songs, works of Ukrainian classical composers. Extremely important is a holistic approach to their assimilation of national culture: the study of history, mastering the aesthetic richness of language, attention to the beauty of the native land. One of the strongest factors of spontaneous aesthetic influence in the system of aesthetic education is nature. This influence is amplified provided that it is organized and managed by the teacher.

Aesthetic education of students is carried out by interpersonal influence between students, students and teachers in the educational process and in extracurricular activities. Aesthetic communication, which includes basic aesthetic skills of behavior, the aesthetics of human relationships at work, life, leisure, with a skillful organization has a powerful educational force.

Key words: aesthetic education, youth, culture, education, spiritual values.

\section{UDC 378.018.54.091.2:784.071.2](510)(043.3)}

Iryna Chystiakova

Sumy State Pedagogical University named after A.S. M akarenko ORCID ID 0000-0001-8645-510X

Zhang Lianhong

Sumy State Pedagogical University named after A.S. Makarenko ORCID ID 0000-0002-7416-3705

DOI 10.24139/2312-5993/2020.10/031-040

\section{WAYS OF VOCALISTS' PROFESSIONAL TRAINING IM PROVEMENT IN THE SYSTEM OF HIGHER MUSIC EDUCATION OF CHINA}

The article identifies the ways to improve the system of vocal training in higher music education institutions of China. The problems of professional vocal education in China are identified and characterized. The ways of solving the mentioned problems in the context of professional training of vocalists in the system of higher music education of China are offered: 1 ) to optimize professional vocal education management; 2 ) to create a national model of professional vocal education; 3 ) to optimally correlate quality and quantity in the process of vocalists' professional training; 4) to overcome isolation; 5) to train highly qualified teaching staff for institutions of higher music education; 6) to modernize the content of education in the process of professional training of vocal art specialists in the system of higher music education; 7) to intensify development and implementation of the methods of teaching vocalists, which would correspond to the new theoretical and methodological foundations of vocalists' professional training; 8) to develop a new working mechanism for graduates employment; 9) to limit the commercialization of education; 10) to develop a new educational model that takes into 